\title{
Socio-Economic Characteristics and Extent of Utilisation of Benefits of Micro Irrigation by Beneficiaries under Prdhan Mantri Krishi Sinchayee Yojana at Belagavi District of Karnataka State
}

\author{
Siddu Badakuri* and N. Manjula \\ Department of Agricultural Extension Education, College of Agriculture, \\ UAS, Dharwad (Karnataka), India \\ *Corresponding author
}

\section{A B S T R A C T}

Keywords

Utilisation, PMKSY, Drip irrigation, Micro irrigation, Crops, Sprinkler irrigation

Article Info

Accepted:

12 December 2020 Available Online: 10 January 2021
The study was carried out in Belagavi district of Karnataka during 2019-20. Based on the utilization of fund allotted for micro irrigation, two taluks having highest and lowest fund utilization were selected, four taluks were selected for the study from each taluk, making a total sample for the study 120. Ex-post facto research design was employed for the study, the data was elicited through personal interview method. The collected data were analysed using appropriate statistical tools. The results revealed that exactly half of beneficiaries $(50.00 \%)$ of belonged to medium extension contact category and more than two fifth $(41.66 \%)$ of the beneficiary farmers had medium level of social participation whereas, 40.00 percent of the beneficiaries belonged to medium utilization category, followed by 31.67 per cent and 28.33 per cent of the beneficiaries belonged to high and low utilization category, respectively.

\section{Introduction}

In developing countries like India, agriculture not only contributes to the country economy but also shapes the fabric of the society. Agriculture was practiced as subsistence farming in the past where farmers produced crops for self-sufficiency in terms of food production but it was not enough to feed whole nation. Hence the new era stared in the name of green revolution in 1960s. With the commencement of green revolution (adoption of high yielding varieties, fertilizers and irrigation), India achieved remarkable improvements in crop production. However, much of such improvements were based on over exploitation of natural resources (International Food Policy Research Institute, IFPRI, 2007).

Water the "Elixir of life" is the most important natural resource. Though 70 per cent of planate Earth is covered water, its usage for human being is very meagre. Raising population, industrialisation and low and uneven distribution of rainfall has 
contributed to lesser availability of water for agriculture. The availability of water depends on various hydro-meteorological factors, and therefore effective use of available water for irrigation is important but a major challenge. On other side due to globalisation, liberalisation and privatization of agriculture in general horticulture in particular, the adoption of modern cultivation practices for higher production is essential Technological innovations and interventions are therefore essential for sustainable agriculture as regards water improvement and supervision. Since water is a valuable resource for farming, every drop of water available in the distribution system and its proper usage is very important for overall farm production. The latest catch phrase in one of the schemes of the central government, Pradhan Mantri Krishi Sinchai Yojana (PMKSY or Agriculture Irrigation Scheme of the Prime Minister), is "Per Drop More Crop." The change to micro-irrigation is apparently thought to "save" water and improve crop yields. Area covered by micro-irrigation (drip and sprinkler) was 81.46 .172 ha in India by 2016 and 9.05.802 ha in Karnataka. (Anon, 2016)

\section{Materials and Methods}

\section{Selection of study area}

Belagavi district of Karnataka was selected for the study because of it has highest irrigation area.

\section{Selection of taluks}

From Belagavi district four taluks were selected based on fund allotted and utilisation for micro irrigation under PMKSY. Two were highest fund utilisation namely Gokak and Chikkodi.

Two were lowest fund utilisation Bailhongal and Belagavi.

\section{Selection of villages}

Ten villages were selected randomly for the present study.

\section{Selection of beneficiary farmers}

From each selected village five beneficiary farmers were selected randomly to constitute the total sample size of 60 .

\section{Tools used for data collection}

Survey is one of the tools used for collecting the relevant information from PMKSY beneficiary farmers. Structured, pretested interview schedule was employed to collect the information from PMKSY beneficiary farmers to elicit information regarding utilisation of micro irrigation under PMKSY. The information was tabulated, analysed by the researcher personally and presented in the result and discussion.

\section{Results and Discussion}

The findings of the present study as well as relevant discussion have been summarized under following heads:

A profile of beneficiary farmers of PMKSY is presented in tabale-1 such as Extension contact, mass media exposure and social participation,

\section{Extension contact}

A cursory look into data in Table-1indicated that exactly half $(50.00 \%)$ of the beneficiary farmers had medium extension contact level, followed by low (33.33\%) and high (16.67\%) extension contact category. Majority of the beneficiary farmers having medium level of source of extension contact may be due to the reason that, respondents were familiar to extension personnel like input dealers and 
also may be due to heterogeneity of the farmers in age and education. Further, farmers visited extension personnel whenever they felt necessary.

Further Table 2 revealed that more than half of the beneficiary farmers monthly contacted input dealers, this might be due to the reason that beneficiary and farmers are in contact with input dealers frequently for purchase of agriculture inputs like fertilizers pesticides, and weedicides next frequently contacted is Agriculture officer which might be due to famers visit agriculture department which is headed by agriculture officer, for subsidies under PMKSY schemes for different inputs. Similarly, for availing services from Agriculture department, they have to contact Horticulture officer.

The present findings had support with findings of Mavinakatti (2013), Hanjabam (2014), Sindhu (2017) and Biradar (2019).

\section{Social participation}

The data in the Table-3revealed the overall distribution of social participation of the beneficiary farmers of PMKSY. Less than half of beneficiary farmers $(41.66 \%)$ of the respondents belonged to medium level social participation, followed by one third $(33.33 \%)$ and one fourth $(25.00 \%)$ were in low and high category, respectively.

It is evident from Table 4 that overall, the participation of the beneficiary farmers of PMKSY in various organizational activities is poor. This might be because vegetables and commercial crop cultivation is an intensive farming activity and most of the vegetables and commercial crop growers have irrigation facility. They have one or other the crops in the field throughout the year and they are busy. Hence, they hardly get any time to participate in different organizational activities. Further, farmers expressed that hardly they get any information related to farming income generation activities from these local organizations that are exist in their area.

Similar findings were observed in the study conducted by Sindhu (2017).

\section{Distribution of PMKSY beneficiaries based on overall utilization}

The result in the Table 5indicates that 40.00 percent of the beneficiaries belonged to medium utilization category, followed by 31.67per cent and 28.33 per cent of the beneficiaries belonged to high and low utilization category, respectively.

The reason might be that, adoption of micro irrigation system requires precise and full knowledge. Majority of the farmers have completed at least middle school level education, semi medium land holding, medium farming experience, more contact with input dealers and medium economic motivation. Hence, all these factors might have influenced the utilization of micro irrigation system. Another Probable reason for the farmers to be in medium utilization category might be due to the medium awareness possessed by the farmers, since awareness limits action of individuals, as it is pre-requisite for any individuals to either adopt or reject a practice.

The findings of the study are supported by Gowtham (2016).

\section{Utilization of Micro irrigation under Pradhan Mantri Krishi Sinchayee Yojana (PMKSY) by the beneficiary farmers}

A cursory look at Table 6 revealed that majority of the farmers expressed extent of utilization of micro irrigation on various 
aspects of Pradhan Mantri Krishi Sinchayee Yojana (PMKSY).

The results in the Table 6 indicated "micro irrigation system prevents the soil erosion" was expressed to greater extent of utilization by beneficiaries $(90.00 \%)$, followed by Micro irrigation helps in uniform application of water to the crops by 76.66 per cent beneficiaries. Reason is that micro irrigation avoids flooding of soil hence prevents soil erosion and emitters and nozzles in micro irrigation system help in uniform application of water to the crops.

Equal per cent of farmers $(75.00 \%)$ were opinioned great utilization of "Micro irrigation enhances the productivity of crops" and "Micro irrigation helps to save the water", followed by equal per cent of farmers $(71.66 \%)$ expressed that "Micro irrigation enhances the water use efficiency of crops" and "Micro irrigation decreases the weed intensity".

Table.1 Overall distribution of beneficiary farmers of Pradhan Mantri Krishi Sinchayee Yojana according to their extension contact $(\mathrm{n}=120)$

\begin{tabular}{|c|l|c|c|}
\hline \multirow{2}{*}{$\begin{array}{c}\text { Sl } \\
\text { No }\end{array}$} & \multirow{2}{*}{ Category } & \multicolumn{2}{|c|}{ Beneficiaries } \\
\hline $\mathbf{1}$ & Low & Frequency & Percentage \\
\hline $\mathbf{2}$ & Medium & 20 & 33.33 \\
\hline $\mathbf{3}$ & High & 30 & 50.00 \\
\hline & Total & 10 & 16.67 \\
\hline & & 60 & 100.0 \\
& & \multicolumn{2}{|c|}{$\begin{array}{c}\text { Mean }=4.25 \mathrm{SD}=1.85 \\
\text { Low }=3.46 \mathrm{High}=5.03\end{array}$} \\
\hline
\end{tabular}

Table.2 Extension contact of the beneficiary farmers of Pradhan Mantri Krishi Sinchayee Yojana (PMKSY $(\mathrm{n}=60)$

\begin{tabular}{|c|c|c|c|c|c|c|}
\hline \multirow[t]{3}{*}{ Sl. No. } & \multirow[t]{3}{*}{ Extension workers } & \multicolumn{5}{|c|}{ Beneficiaries } \\
\hline & & $\begin{array}{c}\text { Once in a } \\
\text { week }\end{array}$ & $\begin{array}{c}\text { Once in a } \\
\text { fort } \\
\text { Night }\end{array}$ & Monthly & Rarely & $\begin{array}{l}\text { Whenever } \\
\text { necessary }\end{array}$ \\
\hline & & $\begin{array}{c}\mathbf{f} \\
(\%)\end{array}$ & $\begin{array}{c}\mathbf{f} \\
(\%)\end{array}$ & $\begin{array}{c}\mathbf{f} \\
(\%)\end{array}$ & $\begin{array}{c}\mathbf{f} \\
(\%)\end{array}$ & $\begin{array}{c}\mathbf{f} \\
(\%)\end{array}$ \\
\hline 1 & Agriculture officer & $\begin{array}{c}02 \\
(03.33)\end{array}$ & $\begin{array}{c}02 \\
(03.33)\end{array}$ & $\begin{array}{c}11 \\
(18.33)\end{array}$ & $\begin{array}{c}13 \\
(21.67)\end{array}$ & $\begin{array}{c}32 \\
(53.34)\end{array}$ \\
\hline 2 & $\begin{array}{l}\text { Assistant director of } \\
\text { agriculture }\end{array}$ & $\begin{array}{c}01 \\
(01.66)\end{array}$ & $\begin{array}{c}03 \\
(05.00)\end{array}$ & $\begin{array}{c}07 \\
(11.67)\end{array}$ & $\begin{array}{c}22 \\
(36.66)\end{array}$ & $\begin{array}{c}27 \\
(45.00)\end{array}$ \\
\hline 3 & Horticulture officer & $\begin{array}{l}- \\
-\end{array}$ & $\begin{array}{l}- \\
-\end{array}$ & $\begin{array}{l}- \\
-\end{array}$ & $\begin{array}{c}02 \\
(03.33)\end{array}$ & $\begin{array}{c}58 \\
(96.67)\end{array}$ \\
\hline 4 & $\begin{array}{l}\text { Assistant director of } \\
\text { horticulture }\end{array}$ & $\begin{array}{l}- \\
-\end{array}$ & - & $\begin{array}{l}- \\
-\end{array}$ & $\begin{array}{l}- \\
-\end{array}$ & $\begin{array}{c}60 \\
(100.0)\end{array}$ \\
\hline 5 & $\begin{array}{l}\text { Agricultural scientists } \\
\text { (University/ KVK) }\end{array}$ & $\begin{array}{l}- \\
-\end{array}$ & $\begin{array}{l}- \\
-\end{array}$ & $\begin{array}{l}- \\
-\end{array}$ & - & $\begin{array}{c}60 \\
(100.0)\end{array}$ \\
\hline 6 & Input dealers & $\begin{array}{l}- \\
-\end{array}$ & $\begin{array}{c}24 \\
(40.00)\end{array}$ & $\begin{array}{c}33 \\
(55.00)\end{array}$ & $\begin{array}{c}02 \\
(03.33)\end{array}$ & $\begin{array}{c}01.00 \\
(01.66)\end{array}$ \\
\hline
\end{tabular}

f-Frequency, (\%-Percentage), Figures in parenthesis indicates 
Table.3 Overall distribution of the beneficiary farmers of Pradhan Mantri Krishi Sinchayee Yojana according to their social participation $(n=60)$

\begin{tabular}{|c|c|c|c|}
\hline \multirow[t]{2}{*}{$\begin{array}{l}\text { SI } \\
\text { No }\end{array}$} & \multirow[t]{2}{*}{ Category } & \multicolumn{2}{|c|}{$\begin{array}{l}\text { Beneficiaries } \\
\qquad(n=60)\end{array}$} \\
\hline & & Frequency & Percentage \\
\hline 1 & Low & 20 & 33.33 \\
\hline 2 & Medium & 25 & 41.66 \\
\hline \multirow[t]{2}{*}{3} & High & 15 & 25.00 \\
\hline & Total & 60 & 100.0 \\
\hline & & \multicolumn{2}{|c|}{$\begin{array}{l}\text { Mean=4.11 SD=1.29 } \\
\text { Low }=3.56 \text { High }=4.65\end{array}$} \\
\hline
\end{tabular}

Table.4 Organization wise social participation of the beneficiary farmers of Pradhan Mantri Krishi Sinchayee Yojana (PMKSY) (n=60)

\begin{tabular}{|c|c|c|c|c|c|c|c|c|c|c|c|}
\hline \multirow[t]{4}{*}{ Sl. No } & \multirow[t]{4}{*}{ Organization } & \multicolumn{10}{|c|}{ Extent of Participation } \\
\hline & & \multicolumn{4}{|c|}{$\begin{array}{l}\text { Nature of } \\
\text { membership }\end{array}$} & \multicolumn{6}{|c|}{ Beneficiaries } \\
\hline & & \multicolumn{2}{|c|}{ Member } & \multicolumn{2}{|c|}{$\begin{array}{l}\text { Office } \\
\text { bearer }\end{array}$} & \multicolumn{2}{|c|}{ Regularly } & \multicolumn{2}{|c|}{ Occasionally } & \multicolumn{2}{|c|}{ Never } \\
\hline & & $\mathbf{f}$ & $\%$ & f & $\%$ & f & $\%$ & $\mathbf{f}$ & $\%$ & $\mathbf{f}$ & $\%$ \\
\hline 1. & Gram Panchayat & 02 & 03.33 & - & - & 02 & 03.33 & 11 & 18.33 & 47 & 78.33 \\
\hline 2. & Co-operative Society & 58 & 96.66 & - & - & 03 & 05.00 & 56 & 93.33 & 01 & 01.66 \\
\hline 3. & SHG & 30 & 50.00 & - & - & 30 & 50.00 & - & - & 30 & 50.00 \\
\hline 4. & Milk union society & 02 & 03.33 & - & - & 37 & 61.67 & - & - & 23 & 38.33 \\
\hline
\end{tabular}

f-Frequency \%-Percentage

Table.5 Overall Utilization of Micro irrigation by the beneficiary farmers of Pradhan Mantri Krishi Sinchayee Yojana (PMKSY) (n=60)

\begin{tabular}{|c|l|c|c|}
\hline Sl. No & \multicolumn{1}{|c|}{ Category } & Frequency & Percentage \\
\hline $\mathbf{1}$ & Low $(<34.60)$ & 17 & 28.33 \\
\hline $\mathbf{2}$ & Medium $(34.61-36.29)$ & 24 & 40.00 \\
\hline $\mathbf{3}$ & High $(>36.30)$ & 19 & 31.67 \\
\hline & Total & 60 & 100.0 \\
\hline & \multicolumn{2}{|c|}{ Mean=35.45 SD=1.98 } \\
\hline
\end{tabular}


Table.6 Extent of Utilization of Micro irrigation by the beneficiary farmers of Pradhan Mantri Krishi Sinchayee Yojana (PMKSY)

\begin{tabular}{|c|c|c|c|c|c|c|c|}
\hline \multirow{3}{*}{$\begin{array}{l}\text { Sl. } \\
\text { No }\end{array}$} & \multirow{3}{*}{ Statement } & \multicolumn{6}{|c|}{ Responses } \\
\hline & & \multicolumn{2}{|c|}{ Great Extent } & \multicolumn{2}{|c|}{ Moderate Extent } & \multicolumn{2}{|c|}{ Less Extent } \\
\hline & & $\mathbf{f}$ & $\%$ & f & $\%$ & $\mathbf{f}$ & $\%$ \\
\hline 1. & $\begin{array}{l}\text { Micro irrigation enhances the } \\
\text { productivity of crops }\end{array}$ & 45 & 75.00 & 15 & 25.00 & 00 & 00.00 \\
\hline 2. & $\begin{array}{l}\text { Micro irrigation helps the farmers to save } \\
\text { the fertilizers }\end{array}$ & 33 & 55.00 & 15 & 25.00 & 12 & 20.00 \\
\hline 3. & $\begin{array}{l}\text { Micro irrigation potentially promotes } \\
\text { fertigation }\end{array}$ & 32 & 53.33 & 16 & 26.66 & 12 & 20.00 \\
\hline 4. & $\begin{array}{l}\text { Micro irrigation increases the income of } \\
\text { farmers by saving labour cost }\end{array}$ & 37 & 61.66 & 16 & 26.66 & 07 & 11.66 \\
\hline 5. & $\begin{array}{l}\text { Micro irrigation enhances the water use } \\
\text { efficiency of crops }\end{array}$ & 43 & 71.66 & 14 & 23.33 & 03 & 05.00 \\
\hline 6. & $\begin{array}{l}\text { Micro irrigation helps in uniform } \\
\text { application of water to the crops }\end{array}$ & 46 & 76.66 & 11 & 18.33 & 03 & 05.00 \\
\hline 7. & $\begin{array}{l}\text { Micro irrigation system prevents the soil } \\
\text { erosion }\end{array}$ & 54 & 90.00 & 06 & 10.00 & 00 & 00.00 \\
\hline 8. & $\begin{array}{l}\text { Micro irrigation can be used in area of } \\
\text { undulated topography }\end{array}$ & 10 & 16.66 & 16 & 26.66 & 34 & 56.66 \\
\hline 9. & $\begin{array}{l}\text { Through micro irrigation, area under } \\
\text { cultivation can be increased }\end{array}$ & 39 & 65.00 & 19 & 31.66 & 02 & 03.33 \\
\hline 10. & $\begin{array}{l}\text { Electricity consumption reduces, after } \\
\text { installation of Micro irrigation system }\end{array}$ & 07 & 11.66 & 15 & 25.00 & 38 & 63.33 \\
\hline 11 & $\begin{array}{l}\text { Micro irrigation motivates the farmers to } \\
\text { grow cash/commercial crops }\end{array}$ & 35 & 58.33 & 21 & 35.00 & 04 & 06.66 \\
\hline 12. & Micro irrigation helps to save the water & 45 & 75.00 & 11 & 18.33 & 04 & 06.66 \\
\hline 13. & $\begin{array}{l}\text { Sprinkler irrigation helps to protect the } \\
\text { crops from high temperature }\end{array}$ & 13 & 21.66 & 07 & 11.66 & 40 & 66.66 \\
\hline 14. & $\begin{array}{l}\text { Micro irrigation decreases the weed } \\
\text { intensity }\end{array}$ & 43 & 71.66 & 17 & 28.33 & 00 & 00.00 \\
\hline 15. & $\begin{array}{l}\text { Micro irrigation influence the farmers to } \\
\text { grow horticulture crops }\end{array}$ & 22 & 36.66 & 20 & 33.33 & 18 & 30.00 \\
\hline
\end{tabular}

f-frequency \%-percentage

Whereas 66.66 per cent were expressed that "Sprinkler irrigation helps to protect the crops from high temperature" has lesser extent of utilization. Reason is that micro irrigation helps application of water directly root zones of crops hence water saved and efficient utilization of water leads to enhance the productivity of crops and also reduces weed growth by avoiding excess moisture surrounding root zone.

65.00 per cent of farmers stated that utilization of "micro irrigation helps farmers to area under cultivation can be increased" in greater extent. Whereas 63.33 per cent farmers voiced utilization of "Electricity 
consumption reduces, after installation of Micro irrigation system" by lesser extent and 61.66 per cent were spoken that "Micro irrigation increases the income of farmers by saving labour cost". The reason is that by utilising of micro irrigation larger area can be irrigated and it also prevents weed intensity and it helps in fertigation so labour cost was reduced.

Nearly three fifth $(58.33 \%)$ of farmers expressed that greater extent utilization of "Micro irrigation motivates the farmers to grow cash/commercial crops" whereas 56.66 per cent of farmers stated that utilization of "Micro irrigation can be used in area of undulated topography" by lesser extent. the reason is that by assured irrigation is given to commercial crops by micro irrigation by saving of water. By using micro irrigation water will be supplied at a constant pressure by using electrical motors so undulated area can be irrigated.

Slightly above the two fourth of farmers $(55.00 \%$ and $53.33 \%)$ were communicated that greater extent utilization of "Micro irrigation helps the farmers to save the fertilizers "and "Micro irrigation potentially promotes fertigation". While only 36.33 per cent of farmers expressed greater extent utilization of "Micro irrigation influence the farmers to grow horticulture crops". The micro irrigation helps application of fertilizers along with irrigation water there by reduces fertilizer cost and another face of irrigation is fertigation. Horticulture crops can be covered under micro irrigation system because of it meets the water requirement of crops and area under irrigation can be increased.

In conclusion the high per cent of beneficiary were belonged to medium extension contact. All most two fourth of beneficiaries had medium level of social participation and "micro irrigation system prevents the soil erosion" was expressed to greater extent of utilization by beneficiaries (90.00\%), followed by Micro irrigation helps in uniform application of water to the crops by 76.66 per cent beneficiaries. Whereas, 40.00 per cent of the beneficiaries belonged to medium utilization category, followed by 31.67 per cent and 28.33 per cent of the beneficiaries belonged to high and low utilization category, respectively.

\section{References}

Bhuriya, R., Sandhya, C. and Swarnakar V.K., 2015, Study of adoption behaviour of drip irrigation system on chilli crop in Barwani district of M.P (India). Int. Org. Sci. Res. J. Agric. Vet. Sci., 8 (12): 12-14.

Biradar, M., 2019.Effectiveness of krishiyantradhare scheme in Belagavi district.M. Sc. (Agri.) Thesis, Univ. Agric. Sci., Dharwad, Karnataka (India).

Deepa, N., 2019, A study on awareness and extent of utilization of crop insurance scheme in chitradurga district of Karnataka.M. Sc. (Ag.) Thesis.Professor JayashankarTelanagana State Agricultural University, Hyderabad (India).

Deepak, C. K. and Mane, S. P., 2019, A Study of Irrigation Intensity of Different Sources in MalshirasTahsil. Int. e-Res. J. Imp.Fac - (SJIF) - 6.261, (CIF) 3.452(2015), (GIF)-0.67.

Gowtham., 2016, Studied on Impact of drip irrigation on grape and sugarcane growers in north Karnataka. $M . S c$ (Agri). Thesis, Univ. Agric. Sci. Dharwad, Karnataka (India).

Hanjabam, S., 2014, Analysis of the profile characteristics and attitude of the farmers, extent of and constraints in taking up precision farming in Kerala. An Int. J. Humanities and Social Sci. 1(2):258-289. 
Mavinakatti, J. S., 2013, Knowledge and opinion of farmers regarding Bhoochetana programme. M. Sc. (Agri.) Thesis, Univ. Agric. Sci., Dharwad, Karnataka (India).

Meti, C. B., 2013, Benefits of drip irrigation and constraints in drip irrigation adoption in Dharwad district of Northern Karnataka. Environ. and Ecology. 31(2A): 632-636.

Rudroju, V., 2013, Awareness, accessibility and utilisation pattern of information and communication technology (ICT) projects by farmers of Belgaum district. M. Sc. (Agri.) Thesis, Univ. Agric. Sci., Dharwad, Karnataka (India).

Sindhu., 2017, Perception of farmers towards custom hiring service center in Dharwad district of Karnataka. M. Sc (Agri). Thesis, Univ.Agric. Sci.,Dharwad, Karnataka (India).

\section{How to cite this article:}

Siddu Badakuri and Manjula, N. 2021. Socio-Economic Characteristics and Extent of Utilisation of Benefits of Micro Irrigation by Beneficiaries under Prdhan Mantri Krishi Sinchayee Yojana at Belagavi District of Karnataka State. Int.J.Curr.Microbiol.App.Sci. 10(01): 2111-2118. doi: https://doi.org/10.20546/ijcmas.2021.1001.243 